\title{
Die Zukunft der Anwaltschaft ist weiblich.
}

\section{Nachbericht der Podiumsdiskussion der Arbeitsgemeinschaft Anwältinnen im DAV am Deutschen Anwaltstag}

\section{Paola Carega}

Mitarbeiterin im Projekt „Anwaltschaft für Menschenrechte und Vielfalt" am Deutschen Institut für Menschenrechte, Berlin

Die große Mehrheit der Anwaltschaft ist nach wie vor männlich, daran gibt es nichts zu rütteln. So stehen den rund 50.000 Anwältinnen in Deutschland mehr als dreimal so viele Kollegen gegenüber. Doch die Frauen holen mächtig auf, das zeigt die Zukunftsstudie des Deutschen Anwaltvereins (DAV), die am 64. Deutschen Anwaltstag vom 6. bis 8. Juni 2013 in Düsseldorf vorgestellt wurde: Um 58 Prozent stieg die Zahl der Anwältinnen zwischen 2003 und 2012. Heute nehmen mehr Frauen als Männer ein Jurastudium auf, und es werden mehr Anwältinnen zugelassen als Anwälte. Grund genug für die Arbeitsgemeinschaft „Anwältinnen im DAV“, im Rahmen des Anwaltstags zur Podiumsdiskussion „Die Zukunft ist weiblich - Wie verändert sich die Anwaltschaft? “ einzuladen.

Vor rund 40 Frauen und Männern bestätigte Kai Gramke vom Wirtschaftsforschungsunternehmen prognos, das die Studie erstellt hat, den unübersehbaren Trend: Das Berufsbild Anwaltschaft ist zwar nach wie vor männlich dominiert,

\section{Anwaltschaft und Diversity}

Nicht nur die Anwaltschaft wird weiblicher, die Gesellschaft insgesamt wird vielfältiger, etwa in Bezug auf Alter, Migrationshintergrund oder Behinderung. Diversity-Kompetenz der professionelle und wertschätzende Umgang mit Vielfalt und Unterschiedlichkeiten - wird damit zu einer Schlüsselqualifikation: Denn diversity-kompetente Anwältinnen und Anwälte können einen diskriminierungs- und barrierefreien Service anbieten und haben ein Bewusstsein für die gesellschaftliche Realität von Vielfalt sowie für Ausschließungsmechanismen wie Rassismus und Diskriminierung beim Zugang zum Recht. Das Projekt „Anwaltschaft für Menschenrechte und Vielfalt" am Deutschen Institut für Menschenrechte möchte Diversity-Kompetenz in der juristischen Aus- und Fortbildung verankern. Verbunden damit sollen Qualifizierungen zu Menschenrechten, wie der Frauenrechtskonvention CEDAW, eine größere Rolle spielen. Das Projekt, das im Rahmen des XENOS-Programms „Integration und Vielfalt" durch das Bundesministerium für Arbeit und Soziales und den Europäischen Sozialfonds gefördert wird, stützt sich dafür auf Kooperationspartner wie das Deutsche Anwaltsinstitut, den Deutschen Anwaltverein und die Bundesrechtsanwaltskammer.

http://www.institut-fuer-menschenrechte.de/de/projektanwaltschaft-fuer-menschenrechte-und-vielfalt.html „doch die Dynamik kommt von den Frauen“. Nicht zuletzt seien junge Anwältinnen im Schnitt besser qualifiziert als ihre Kollegen. Aber: „Bei den Zukunftsfeldern sind Anwältinnen untervertreten“, bedauerte Gramke. So seien Frauen in den besonders zukunftsträchtigen Fachgebieten Informationstechnologierecht, Bank- und Kapitalmarktrecht sowie Urheberund Medienrecht durchweg in der Minderheit.

Prognos hat für die 190-seitige Studie zur Zukunft des Rechtsdienstleistungsmarkts sowohl selbständige Rechtsanwältinnen und Rechtsanwälte befragt als auch über 5000 Kanzleiinhaberinnen und -inhaber beziehungsweise Partnerinnen und Partner. Die Ergebnisse zeigen, dass Frauen sehr viel seltener Partnerin sind in einer mittelgroßen Sozietät und seltener in großen Kanzleien von mehr als elf Rechtsanwälten arbeiten. Und: Rechtsanwältinnen sind häufiger für ein geringeres Jahreseinkommen tätig, auch bei gleicher Position und Qualifikation. Entsprechend ist knapp die Hälfte der Anwältinnen mit dem Verhältnis von Arbeitseinsatz und wirtschaftlichem Einkommen unzufrieden. Das fünfköpfige Podium (RAin Dr. Margarete Gräfin von Galen; RAin Eva Kubn; RA Patrick Ruppert; RA Dr. Michael Streck; Moderation RAin Silvia C. Groppler, Vorsitzende der Arbeitsgemeinschaft Anwältinnen) zeigte sich hier gespalten. DAV-Vorstandsmitglied Eva Kuhn führte aus, dass Mandanten eher bereit seien, einem Anwalt mehr zu zahlen als einer Anwältin. Die Strafrechtlerin Dr. Margarete Gräfin von Galen hingegen begründete den Vergütungsunterschied damit, dass Frauen häufig ein niedrigeres Honorar als Männer verlangten.

Die Studie zeigt auch Einstimmigkeit zwischen den Geschlechtern. Im Wettbewerb um Fachkräfte etwa halten sowohl Frauen als auch Männer eine Work-Life-Balance für erforderlich. Gleichzeitig ist rund ein Viertel der Anwältinnen und Anwälte unzufrieden mit der Vereinbarkeit von Familie und Beruf (Frauen 29\%, Männer 23,4\%). „Kanzleien unternehmen zu wenig, um die vielen top ausgebildeten Frauen heranzuziehen“, kritisierte Gramke und schlug eine freiwillige Quote als Anreiz vor, damit Kanzleien unter Druck nach Lösungen suchten, ihre Strukturen familienfreundlicher zu gestalten. Während der frühere DAV-Präsident Michael Streck dazu aufrief, möglichst früh Kinder zu kriegen, betonten seine Podiumsmitstreiterinnen und auch Stimmen aus dem Publikum, dass es in jeder Lebensphase möglich sein müsse, eine Familie zu gründen. „Die Vereinbarkeit von Beruf und Familie ist eine gesellschaftliche Aufgabe und nicht Sache der Frauen“, sagte von Galen. Am Ende der zweistündigen Podiumsdiskussion klang Gramkes Fazit zur Zukunft der Anwältinnen versöhnlich. Die zunehmende Digitalisierung werde die Kommunikation der Anwaltschaft weiter verändern. „Dank E-Mail und Skype wird das persönliche Zusammentreffen mit dem Mandanten weniger wichtig“, sagte Gramke. Dies schaffe flexiblere Arbeitszeitmodelle, was gerade Frauen zu Gute kommen würde. Und auch der Anwaltschaft insgesamt: 
Denn die Anwaltschaft wird vielfältiger, ebenso wie die Mandantschaft, etwa in Bezug auf ethnische Herkunft, Behinderung und Alter. Gender und Vielfalt sind damit nicht nur Zukunftsthemen, sondern jetzt von der Anwaltschaft anzugehen.

\section{Gender and Judging}

\section{Edited by Ulrike Schultz and Gisela Shaw}

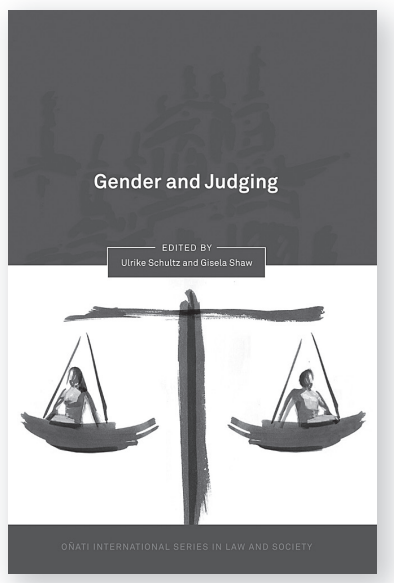

Does gender make a difference to the way the judiciary works and should work? Or is genderblindness a built-in prerequisite of judicial objectivity? If gender does make a difference, how might this be defined? These are the key questions posed in this collection of essays, by some 30 authors from the following countries; Argentina, Cambodia, Canada, England, France, Germany, India, Israel, Italy, Ivory Coast, Japan, Kenya, the Netherlands, the Philippines, South Africa, Switzerland, Syria and the United States. The contributions draw on various theoretical approaches, including gender, feminist and sociological theories.

The book's pressing topicality is underlined by the fact that well into the modern era male opposition to women's admission to, and progress within, the judicial profession has been lar- gely based on the argument that their very gender programmes women to show empathy, partiality and gendered prejudice - in short essential qualities running directly counter to the need for judicial objectivity. It took until the last century for women to begin to break down such seemingly insurmountable barriers. And even then, there are a number of countries where even this first step is still waiting to happen. In all of them, there remains a more or less pronounced glass ceiling to women's judicial careers.

Ulrike Schultz is a senior academic in law at the FernUniversität in Hagen, Germany. She heads the International Working Group on the Comparative Study of Legal Professions and has been a member of the Oñati International Institute for the Sociology of Law Governing Board since 2006.

Gisela Shaw, Emeritus Professor of German Studies at the University of the West of England, Bristol, UK, has worked and published in philosophy, literature and legal sociology.

July 2013 640pp Hbk 9781841136400 RSP: $£ 50 / € 65$

\section{Gender and Judging - Women in the World's Legal Professions - JurPro}

Der Sammelband Gender and Judging ist das Ergebnis langjähriger international vergleichender Arbeiten in der Women/Gender in the Legal Profession Group, einer Untergruppe der International Working Group for Comparative Studies of the Legal Profession. Es wird der Band Women in the World's Legal Professions ergänzt und fortgeführt, der 2003 ebenfalls bei Hart Publishers in Oxford erschienen ist und den Schwerpunkt auf der Berufs- und Lebenssituation von Anwältinnen hatte. ${ }^{1}$ Weitere Artikel zu Gender and Judging finden sich in einem Sonderheft des International Journal of the Legal Profession. ${ }^{2}$ Einer der deutschen Beiträge in Gender and Judging basiert auf einer empirischen Untersuchung zu Frauen in Führungspositionen der Justiz in NRW, die von einer Hagener Forscherinnengruppe durchgeführt worden ist. ${ }^{3}$

Der Fokus der Arbeiten richtet sich mittlerweile auf eine dritte Gruppe von Juristinnen, die Rechtswissenschaftlerinnen in juristischen Fakultäten, anknüpfend an das vom BMBF im Programm „Frauen an die Spitze“ an der FernUniversität geförderte Projekt „JurPro“ - De jure und de facto: Professorinnen in der Rechtswissenschaft. 2015 soll zu diesem Projekt ein internationaler Workshop durchgeführt werden, vorab werden bei den nächsten rechtssoziologischen Tagungen und beim Treffen der Legal Profession Group in Frauenchiemsee vom 6.-9. Juli 2014 Panels zur Situation der Juraprofessorinnen anberaumt.

\section{Informationen:}

JurPro: http://www.fernuni-hagen.de/jurpro/ Legal Profession Group: http://rcsl.iscte.pt/rcsl_wg_professions. htm ; http://iwglp.wordpress.com/ International Institute for the Sociology of Law http://www.iisj.net/ UlrikeSchultz Ulrike.Schultz@FernUni-Hagen.de

1 Schultz, Ulrike und Gisela Shaw: Women in the World's Legal Professions. Oxford: Hart 2003. Vgl. auch Schultz, Ulrike: Women in the World's Legal Profession - Die Geschichte eines Projekts. In: Aktuelle Informationen des Juristinnenbundes 2003, S. 91-93.

2 Schultz, Ulrike und Gisela Shaw, Hrsg.: Special Issue: Gender and Judging des International Journal of the Legal Profession, Volume 15, numbers 1-2, March - July 2008, auch erschienen als Sonderband Women in the Judiciary. London, New York: Routledge 2012.

3 Schultz, Ulrike: “I was noticed and I was asked ..." Women's Careers in the Judiciary. Results of an empirical study for the Ministry of Justice in Northrhine--Westfalia, Germany, S. 145-166. Schultz, Ulrike (2012): Frauen in Führungspositionen der Justiz. Deutsche Richterzeitung, S. 264-272. 